\title{
Technical and Non-Technical Programme Students' Attitudes and Reasons for Plagiarism
}

\author{
Madhubala Bava Harji ${ }^{1}$, Zalina Ismail ${ }^{1}$, Thiba Naraina Chetty $^{1} \&$ Krishnaveni Letchumanan ${ }^{1}$ \\ ${ }^{1}$ Faculty of Applied Communication, Multimedia University, Malaysia \\ Correspondence: Thiba Naraina Chetty, Faculty of Applied Communication, Multimedia University, Malaysia. \\ Tel: 012-7675-073. E-mail: thibasaravanan@gmail.com
}

Received: August 20, 2017 Accepted: October 13, 2017 Online Published: October 16, 2017

doi: 10.5539/elt.v10n11p141 URL: http://doi.org/10.5539/elt.v10n11p141

\begin{abstract}
To date, plagiarism continues to be a widespread problem in higher education. Deemed to be endemic, researchers continue to examine various aspects of plagiarism, including students' perception, practices, attitudes and reasons for plagiarism, in addressing this growing concern. Most studies, however, tend to examine these aspects independently. This paper reports on a study that examined both the students' attitudes and reasons for plagiarism, particularly among the Technical and Non-Technical programme students. A questionnaire was administered to 120 students, i.e. 60 each from each programme to gather quantitative data on their attitudes and reasons for plagiarising. The study found that students in both groups hold negative attitudes towards plagiarism. They deem it synonymous to cheating in final examinations and advocate severe penalty to offenders who submit free downloaded or purchased articles. However, they disagree on being penalised for permitting their peers to plagiarise their work. Significant differences were found for the latter two attitudes between the groups. Albeit, disfavouring plagiarism, the two most cited reasons that compel students in both groups to plagiarise are their self-inadequacy in writing skills and poor time management, followed by the temptation and opportunity to plagiarise from the internet and to cope with the institutional load. With an understanding of these variables, all parties will be able to make more informed decisions in addressing this malpractice and upholding academic integrity.
\end{abstract}

Keywords: attitude, reasons, plagiarism, technical and non-technical programme students

\section{Introduction}

To date, the issue of plagiarism continues to prevail in higher education and this academic dishonesty appears to be here to stay. It is deemed as "endemic to the college and university campus" (Pulvers \& Diekhoff, 1999) and has now possibly reached a "tipping point" (Brady, 2006). Researchers point to either students themselves who accidentally, unintentionally, or intentionally plagiarise (Maurer et al., 2006) or educators and institutions who appear to be 'not doing enough' to address it, which then possibly lands to why it appears to persist in higher institutions of learning. Are all relevant parties in sync in curbing this academic malpractice, dishonesty or unethical behaviour? Macdonald and Carroll (2006) called for a shared responsibility among students, educators and institutions to uphold academic integrity. However, before any shared responsibility can be made, we need to address the root cause, i.e. to the why and what compels students to engage in plagiarism in the first place. Hence, the purpose of the study was to examine students', i.e. specifically Technical programme (TP) and Non-Technical programme (NTP) attitudes and reasons for plagiarism.

\section{Literature Review}

The issue of plagiarism is prevalent and in Paldy's (1996) words, "the problem (of plagiarism) won't go away". In higher education institutions, plagiarism is a recurring problem (Jiang, Emmerton, \& Mckange, 2013). While educators and institutions frown on it and view the act of plagiarism as a serious disciplinary issue, students take another stand (Higbee \& Thomas, 2000) or as Klein (2011) noted, they have a "cavalier attitude". Their attitudes are largely different (Devlin, 2003). They appear to hold a pompous, accusatory, lackadaisical and indifferent attitude towards plagiarism. Gururajan and Roberts (2005) found students "justifying plagiarism" and think that heavy punishment should be imposed only "if substantial amount is reproduced" (p. 1578). They do not consider it an act "against their ethical values" (p. 1578). Songsriwittaya et al. (2009) reported similar findings, i.e. students disregarding copying their peers' work as unethical because they seem to believe that, copying a friend's 
work is not an act of plagiarism as long as they have their consent. Rezanejad and Rezaei (2013) also reported of students' disregard for academic integrity. The act of plagiarism is taken lightly; they plagiarise for fun or because everyone else is doing it.

Students' audacious attitudes towards plagiarism are also elaborated in the typology of reasons below.

With such presumptuous attitudes, it is not surprising to find varied underlying reasons for plagiarism (Zobel \& Hamilton, 2002). Park (2003) reviewed Stevens and Stevens' (1987), Davis et al.'s (1992), Love and Simmons' (1998) and Straw's (2002) work and drew up a "typology of reasons" for plagiarising. We added other works of Davis and Ludigson (1995), Devlin and Gray (2007), Akbulut et al. (2008), Abdolmohammadi and Baker (2008), Erkaya (2009), Songsriwittaya et al. (2009), Owunwanne, Rustagi and Dada (2010), Eret and Gokmenoglu (2010), Simkin and McLeod (2010), Comas-Forgas and Sureda Negre (2010), Gross (2011), Jones (2011), Rezanejad and Rezaei (2013), Hosny and Fatima (2014), and Debnath (2016) to reference similar findings as well as to expand Park's typology:

(i) "Genuine lack of understanding": This can be seen from three perspectives, i.e. lack of academic skills pertaining to plagiarism, lack of knowledge of subject matter and lack of awareness about plagiarism. Firstly, lack of academic skills includes lack of knowledge on how to quote, paraphrase, cite and reference (Park, 2003; Devlin \& Gray, 2007; Eret \& Gokmenoglu, 2010) and "knowledge of writing research papers". Secondly, lack of understanding of subject matter is seen in students' lack of general knowledge or ability to understand or comprehend information" (Akbulut et al., 2008; Jones, 2011; Eret \& Gokmenoglu, 2010). Thirdly, students' "lack of awareness about plagiarism" (Erkaya, 2009; Eret \& Gokmenoglu, 2010), its severity and its consequences of plagiarising as well as the university regulations (Rezanejad \& Rezaei, 2013).

(ii) "Efficiency gain": Students are found to plagiarise to obtain "better grades" (Park 2003; Songsriwittaya et al., 2009; Jones 2011; Hosny \& Fatima, 2014), "to save time" (Park, 2003) and for fear of career prospects (Hosny \& Fatima, 2014).

(iii) "Time management" is a result of external pressure, including "active social life, commitment to college sports and performance activities, family responsibilities" (Park, 2003; Akbulut et al., 2008) or "external work commitments" (Hosny \& Fatima, 2014). The "pressure to complete multiple work assignments in short amounts of time" (Park, 2003; Hosny \& Fatima, 2014) could be reflective of students' poor personal management of time. Being too busy (Rezanejad \& Rezaei, 2013) and consequently having insufficient time to complete assignments could possibly lead to the need to plagiarise in order for timely completion of tasks.

(iv) "Personal values and attitudes" include firstly, "social pressure (Park, 2003; Jones, 2011), because attaining higher grades makes students feel good (Songsriwittaya et al., 2009; Hosny \& Fatima, 2014) or "because they regard short cuts as clever and acceptable" (Park, 2003). Students' pompous attitude is evident as they take "pride in plagiarising" (Devlin and Gray, 2007). Secondly, peer pressure. Owunwanne, Rustagi and Dada (2010), Rezanejad and Rezaei (2013) and Akbulut et al. (2008) added peer pressure, i.e. students "trying to show off towards the opposite sex and trying to impress friends, or peer competitiveness (Hosny \& Fatima, 2014). Other forms of pressure, include family pressure, i.e. "high family expectations" (Hosny \& Fatima, 2014) and self-imposed pressure, i.e. the "desire to succeed" in attaining higher goals (Hosny \& Fatima, 2014; Simkin \& McLeod, 2010). Students' lackadaisical attitudes are seen in their procrastination to complete assignments (Jones, 2011), laziness (Devlin and Gray, 2007) or disinterest in subject or assignment (Eret \& Gokmenoglu, 2010; Jones, 2011).

(v) "Defiance": Students' intentional involvement in plagiarism could be a form of rebelliousness or "lack of respect for authority". Deeming assignments as "neither important nor challenging" (Park, 2003) are also found to be grounds for plagiarism.

(vi) "Attitude towards teacher and class": Park (2003) cited Howard (2002) in noting that students' "negative attitudes towards assignments and tasks that teachers think have meaning but they don't" or as Akbulut et al. (2008) highlighted, students deem assignments as uninteresting. They could be of opinion that their teachers do not "bother to read their papers or closely review their work" (Burnett, 2002 cited in Park, 2003) or that it "does not matter to the teacher" (Jones, 2011) and hence plagiarised papers would not be detected. Owunwanne, Rustagi and Dada (2010) cited "lack of preparedness", which could also be reflective of students' lackadaisical attitude towards their class or subject and their poor time management.

(vii) "Denial or neutralism": Students' accusatory attitudes are seen when they legitimise their acts of plagiarism by "passing the blame on to others" (Park, 2003). Jones (2011) found students 'neutralising' their act 
of plagiarising by assuming that "everyone does it and get away with it" and hence, it should be acceptable. Rezanejad and Rezaei (2013) too found similar reasons in their study.

(viii) "Temptation and opportunity": The temptation to plagiarise perhaps cannot be resisted with the available opportunities of quickly cutting and pasting (Park, 2003; Akbulut et al., 2008; Owunwanne, Rustagi \& Dada, 2010; Comas-Forgas \& Sureda Negre, 2010; Debnath, 2016) the easily accessible world of information from the internet. Gross (2011) remarked that students "hold communal interaction and collaboration in the highest regard" and therefore regard information that is shared publicly on the Internet is free for all. Hence, students believe it requires no acknowledgement.

(ix) "Lack of deterrence": Park (2003) highlighted that for students' indifferent attitude towards plagiarism, i.e. that the "benefits of plagiarising outweigh the risks, particularly if they think there is little or no chance of getting caught and there is little or no punishment if they are caught" (Davis \& Ludvigson, 1995; Eret \& Gokmenoglu, 2010; Simkin \& McLeod, 2010). Akbulut et al. (2008), Comas-Forgas and Sureda Negre (2010), and Jones (2011) noted teachers' disinterest in students' engagement in plagiarism could also a reason or as Simkin and McLeod (2010) noted because they are reluctant to act upon such academic dishonesty. Rezanejad and Rezaei (2013) too found students citing teacher's lack of attention and lackadaisical attitude. Students found no discretion in terms of marks between plagiarised and non-plagiarised papers; they received the same treatment.

As mentioned earlier, with additional review of other works by Devlin and Gray (2007), Akbulut et al. (2008), Eret \& Gokmenoglu (2010), Comas-Forgas and Sureda Negre (2010), Rezanejad and Rezaei (2013), Jones (2011) and Debnath (2016), we have added to Park's (2003) typology of the reasons, the following:

(x) Institutional load, includes "inadequate admission criteria, poor and education costs" (Devlin \& Gray, 2007), tight workload (Jones, 2011) or class schedules and difficulty of assignments, "heavy course loads" (Comas-Forgas \& Sureda Negre, 2010; Eret \& Gokmenoglu, 2010).

(xi) Students' inadequacies: Students may be compelled to plagiarise as they lack confidence (Debnath, 2016), which could be due to their lack of proficiency (Eret \& Gokmenoglu, 2010) in the target language and writing skills (Debnath, 2016). This could consequently lead to being more confident in the original text (Rezanejad \& Rezaei, 2013). Their poor academic writing skills (Pecorari \& Petric, 2014) and restricted ability to rephrase text in their own words could also give grounds for plagiarising.

In studies where students were required to indicate their reasons for engaging in plagiarism, a frequency count of students' responses in Jones' (2011) study found grades, procrastination and lack of understanding/inability to comprehend information were the three most frequently cited reasons. Conversely, the three least cited reasons were: "everyone does it and get away with it, no big deal; does not matter to professor and peer pressure". Jones noted that Synder and Cannoy (2010) too found similar reasons. Eret and Gokmenoglu (2010), on the other hand, found "problems with using foreign language, time constraints and lack of knowledge about plagiarism" as the three most cited reasons and "lack of enough academic skills, lack of respect or interest for the course and lack of punishment for the plagiarism" as the three least cited reasons.

We continue to see a rising trend and this trend, according to Berlinck (2011), is particularly evident in "English speaking countries". Undeniably, the upward trend for plagiarism among non-English speaking countries is also emerging. Researches have shown that this trend is becoming prevalent in Asian countries too (Ehrich, et al., 2014). Albeit studies in Asian countries, particularly in Malaysia are limited, Smith (2007), Iberahim, et al., (2013), Ting (2013), Mah and Ting (2013), Musa and Ting (2013); Ting, Musa and Mah (2014), Jansz and Sari (2015), Cheah (2015), Razali et al. (2016), and Bava Harji, Chetty, Ismail and Letchumanan (2016) have provided evidence for plagiarism being equally rampant in non-English speaking countries. Thus, concurring with Adbolmohammadi and Baker (2007), "to combat this worrisome situation, it is important to investigate the variables that are associated with plagiarism": What are the students' attitudes towards plagiarism? Why do students engage in plagiarism? Is there a driving 'force' that compels students to plagiarise? A study has yet to be carried out to examine both the students' attitudes and reasons why they plagiarise in non-English speaking countries. Most studies examine attitudes or reasons for plagiarising independently of each other. This study thus extended the existing studies to examine both these variables, particularly among students in the Technical and Non-Technical programmes. Below are the research objectives and research questions that guided the study.

\subsection{Research Objectives}

The objectives of the research were to examine the students' (a) attitudes towards plagiarism and (b) reasons for plagiarism, specifically among the TP and NTP students.

\subsection{Research Questions}


The research, thus addressed the following research questions:

1) What are the students' attitudes towards plagiarism?

2) What are the Technical and Non-Technical programme students' attitudes towards plagiarism?

3) What are the students' reasons for plagiarism?

4) What are the Technical and Non-Technical programme students' reasons for plagiarism?

\section{Method}

\subsection{Participants}

120 undergraduates (60 students each undertaking TP (Technical) and NTP (Non-Technical programmes) in an institution of higher learning participated in the study. Although an equal number of males and females were involved, the proportion of students by gender varied by programme; the male TP students outnumbered the female, but vice versa for the NTP students. They also varied in their year of studies, i.e. with the third year students (58 students) forming the largest proportion, followed by the first year students (38 students) and subsequently the second year (19 students) and the fourth year students (5 students). Of the 120 students, 65 $(54.2 \%)$ students recorded a grade point average (GPA) of between 3.0 to 4.0 points. Table 1 presents additional details of the students' background information.

Table 1. Background information of students

\begin{tabular}{|c|c|c|c|}
\hline \multicolumn{2}{|c|}{ Types of Programme } & Technical Programme & Non-Technical Programme \\
\hline \multirow{2}{*}{\multicolumn{2}{|c|}{ Total Number of Students }} & No $(\%)$ & No $(\%)$ \\
\hline & & $60(50.0)$ & $60(50.0)$ \\
\hline \multirow{2}{*}{ Gender } & Male $(n=60)$ & $34(56.7)$ & $26(43.3)$ \\
\hline & Female $(n=60)$ & $26(43.3)$ & $34(56.7)$ \\
\hline \multirow{4}{*}{ Year of study } & Year $1(n=38)$ & $30(50.0)$ & $8(13.3)$ \\
\hline & Year $2(n=19)$ & $0(0.0)$ & $19(31.7)$ \\
\hline & Year $3(n=58)$ & $27(45.0)$ & $31(51.7)$ \\
\hline & Year $4(n=5)$ & $3(5.0)$ & $2(3.3)$ \\
\hline \multirow{5}{*}{ GPA } & $<1.99(n=1)$ & $1(1.7)$ & $0(0.0)$ \\
\hline & $2.0-2.49(n=19)$ & $16(26.7)$ & $3(5.0)$ \\
\hline & $2.5-2.99(n=35)$ & $14(23.3)$ & $21(35.0)$ \\
\hline & $3.0-3.49(n=45)$ & $21(35.0)$ & $24(40.0)$ \\
\hline & $3.5-4.0(n=20)$ & $8(13.3)$ & $12(20.0)$ \\
\hline
\end{tabular}

$N=120$.

A frequency count on the act of plagiarism found that it appears to be common among approximately 60 per cent of the students; however, only less than two per cent reported they always plagiarise. This is a clear indication that it is not a habitual act. Rather, as seen in Table 2, it appears to be an act that is sometimes ( $32.5 \%$ students) or seldom (29.2\% students) practised. 
Table 2. Frequency of plagiarism of TP and NTP students

\begin{tabular}{|c|c|c|c|c|c|}
\hline & & Frequenc & agiarism & & \\
\hline & & Yes & & & No \\
\hline & & Always & Sometimes & Seldom & Never \\
\hline & & No $(\% *)$ & No $(\% *)$ & No $(\% *)$ & No $(\% *)$ \\
\hline Types of & Technical $(n=60)$ & $1(1.7)$ & $26(43.3)$ & $16(26.7)$ & $17(28.3)$ \\
\hline Programme & Non-Technical $(n=60)$ & $1(1.7)$ & $13(21.6)$ & $19(31.7)$ & $27(45.0)$ \\
\hline Total & & $2(1.6)$ & $39(32.5)$ & $35(29.2)$ & \\
\hline Total $(n=120)$ & & $76(63.3)$ & & & $44(36.7)$ \\
\hline
\end{tabular}

*Note: Percentage refers to percentage within type of programme.

The act of plagiarism also appears to be not prevalent among the students in both programmes. However, the TP students have a greater tendency to plagiarise compared to the NTP students (TP: 71.7\% students; NTP: $55 \%$ students). This is seen in the larger proportion of TP students plagiarising sometimes (43.3\%), compared to the NTP students, who mostly reported they seldom ( $31.7 \%$ students) plagiarise. Thus, it is not surprising to find a larger proportion of NTP students (45\% students) reporting that they do not plagiarise, compared to the TP students (28.3\% students). The Pearson Chi-Square test results in Table 3 show that with a significant level set at 0.05 , the difference in frequency of plagiarism between the two programmes is not significant $\left(\chi^{2}(3, N=120)=\right.$ $6.863, p=.076)$.

Table 3. Pearson Chi-Square test results for frequency of plagiarism between programmes

\begin{tabular}{llll}
\hline & Value & df & Asymp. Sig (2 sided) \\
\cline { 2 - 4 } Pearson Chi-Square & 6.863 & 3 & .076 \\
\hline
\end{tabular}

\subsection{Instruments}

A questionnaire, which comprised three parts, i.e. Part 1 on background information, Part 2 on attitudes towards plagiarism and Part 3 on reasons for plagiarism, was designed to gather data on the students' attitudes and reasons for plagiarism. Data gathered in Part 1 have been presented in Tables 1 and 2.

Part 2 was an adoption of Harris' (2001) 12 statements, which are on a five-point Likert-type scale. As per Ehrich et al. (2015), the scales were scored as: Strongly Agree $=4$, Agree $=3$, Neutral $=2$, Disagree $=1$, Strongly Disagree $=0$; with scores ranging as low as 0 and as high as 48 . It was aimed to be indicative that students with lesser serious attitudes towards plagiarism would score higher than those with greater serious attitudes towards plagiarism. Similarly, reversed scores were awarded to the negative statements $(2,3,7,8$ and 12). The Pearson correlations were calculated and only five statements recorded a reliability of more than 0.7 . The statements are:

S1: "Plagiarism is as bad as cheating in the final examination."

S2: "If a student buys or downloads a whole article for free and submits it unchanged, but puts his/her name as the author, the student should be terminated."

S3: "It is acceptable to submit something you have written previously as a new assignment because you cannot plagiarise yourself."

S4: "If students, who are caught plagiarising received a special grade (such as an FP - Fail for Plagiarising) on their permanent transcript for cheating, that policy would discourage many from plagiarising."

S5: "I should not be penalised, if I allow another student to copy my assignment."

Part 3, which was an adapted version of Foltýnek, Kravjar and Glendinning's (2014) questionnaire, recorded a reliability of Cronbach alpha .801 .

\section{Results}

The data gathered was analysed using the SPSS software and the results are presented in the form of both descriptive and inferential statistical data. The significant threshold as stated earlier was set at 0.05 . The results 
are presented in answer to the research questions.

Research question 1: What are the students' attitudes towards plagiarism?

The analysis of the students' attitudes is presented in terms of mean scores in Figure 1. As mentioned earlier in the method section, students with lesser serious attitudes would score higher than those with greater serious attitudes towards plagiarism.

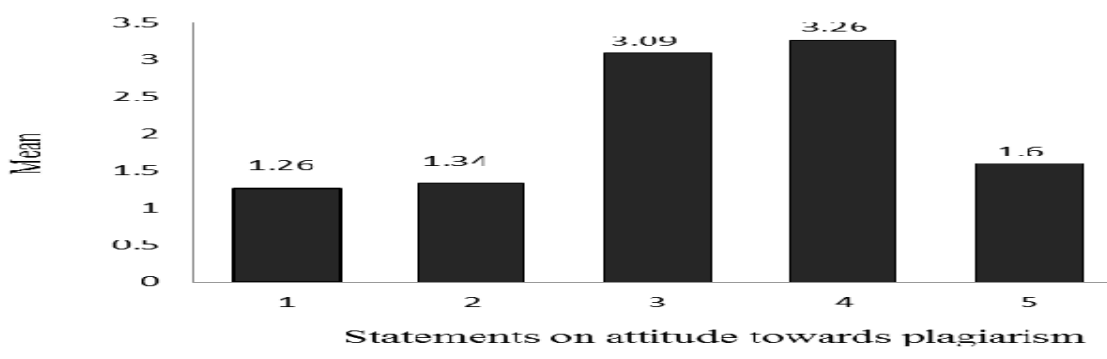

Figure 1. Students' attitudes towards plagiarism

Of the 5 statements, statements 1, 2 and 5 recorded mean scores of less than 2, with students being most serious about plagiarism being synonymous to cheating in final examinations (S1). Students also feel that others, who submitted free downloaded or purchased articles should be more severely punished by being terminated (S2), but that they should not be penalised for granting permission to their peers to copy their assignments (S5). Students, however, are least concerned with having a policy to discourage plagiarism (S4) or with self-plagiarism (S3). These statements recorded mean scores of more than 3 points.

An analysis was also made to examine the correlation between the students' attitudes towards plagiarism and their act of plagiarism and the results of the Pearson Chi-Square test of the cross tabulation are presented in Table 4.

Table 4. Pearson Chi-Square test results for students' attitudes towards plagiarism by act of plagiarism

\begin{tabular}{|c|c|c|c|}
\hline & Value & df & $\begin{array}{l}\text { Asymp. Sig } \\
\text { (2-sided) }\end{array}$ \\
\hline 1. Plagiarism is as bad as cheating in the final examination. & 3.854 & 3 & .278 \\
\hline $\begin{array}{l}\text { 2. If a student buys or downloads a whole article for free and submits it unchanged, } \\
\text { but puts his/her name as the author, the student should be terminated. }\end{array}$ & 3.067 & 3 & .381 \\
\hline $\begin{array}{l}\text { 3. It is acceptable to submit something you have written previously as a new } \\
\text { assignment because you cannot plagiarise yourself. }\end{array}$ & 1.560 & 2 & .458 \\
\hline $\begin{array}{l}\text { 4. If students, who are caught plagiarising received a special grade (such as an FP - } \\
\text { Fail for Plagiarising) on their permanent transcript for cheating, that policy would } \\
\text { discourage many from plagiarising. }\end{array}$ & .780 & 2 & 677 \\
\hline 5. I should not be penalised, if I allow another student to copy my assignment. & 1.914 & 3 & .590 \\
\hline
\end{tabular}

No significant differences are found between students' attitudes towards plagiarism and their act of plagiarism for all 5 statements. This is indicative that the students who admitted that they plagiarise appear to display similar attitudes towards plagiarism as those who reported they do not plagiarise.

Research Question 2: What are the Technical and Non-Technical programme students' attitudes towards plagiarism?

A further analysis, which was made to examine the TP and NTP students' attitudes found that the NTP students recorded slightly higher mean scores than the TP students. 


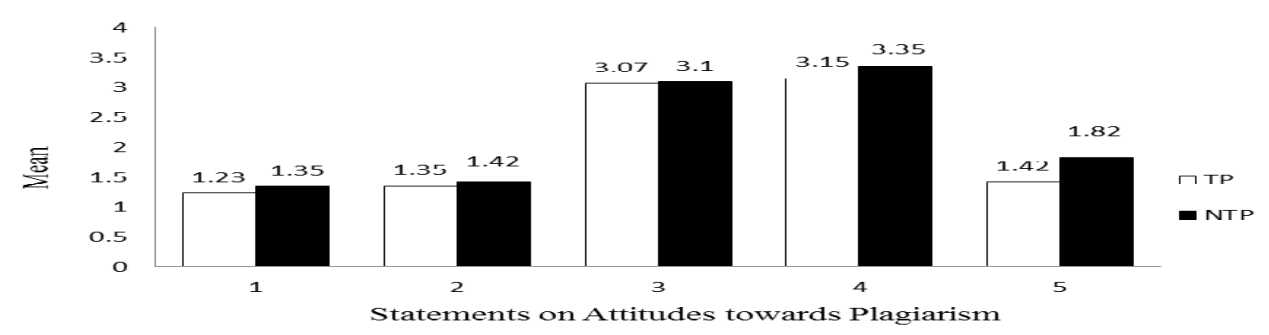

Figure 2. Technical and Non-Technical programme students' attitudes towards plagiarism

As we have seen in Figure 1, students in both programmes recorded higher mean scores $(M>3)$ for statements 3 and 4. However, a closer examination of the students' attitudes by programmes found that NTP students are slightly less concerned with having policies to discourage plagiarism than the TP students $(M D=0.2)$. They, however, expressed similar attitudes towards self-plagiarism.

Although students in both programmes view plagiarism as synonymous to cheating in examinations (S1) and are of opinion that those caught plagiarising ought to be terminated (S2); the TP students appear to regard it slightly more seriously than the NTP students $(\mathrm{S} 1: M D=0.12 ; \mathrm{S} 2: M D=0.07)$. Their attitudes towards being penalised for granting their peers to copy their work are slightly more varied $(M D=0.4)$.

A Pearson Chi-Square test analysis was also conducted to examine if the students in the two programmes differed in their attitudes towards plagiarism. The results showed that significant differences were found between the students in the two programmes, particularly in terms of their attitudes towards terminating those who submit free articles as their own $\left.(\mathrm{S} 1): \chi^{2}(3, N=120)=12.295, p=.006\right)$ and in their self-defence for allowing their peers to copy their work (S5): $\left(\chi^{2}(3, N=120)=8.478, p=.037\right)$. However, no significant differences were found in students' perceiving plagiarism as a serious offence, i.e. cheating in examinations (S1), self-plagiarism (S3) and having a policy to deter plagiarism (S4). The results are presented in Table 5.

Table 5. Pearson Chi-Square test results for students' attitudes toward plagiarism by programme

\begin{tabular}{|c|c|c|c|}
\hline & Value & df & $\begin{array}{l}\text { Asymp. Sig } \\
\text { (2-sided) }\end{array}$ \\
\hline 1. Plagiarism is as bad as cheating in the final examination. & 1.756 & 3 & .624 \\
\hline $\begin{array}{l}\text { 2. If a student buys or downloads a whole article for free and submits it } \\
\text { unchanged, but puts his/her name as the author, the student should be terminated. }\end{array}$ & 12.295 & 3 & .006 \\
\hline $\begin{array}{l}\text { 3. It is acceptable to submit something you have written previously as a new } \\
\text { assignment because you cannot plagiarise yourself. }\end{array}$ & 4.342 & 2 & .114 \\
\hline $\begin{array}{l}\text { 4. If students, who are caught plagiarising received a special grade (such as an } \\
\text { FP - Fail for Plagiarising) on their permanent transcript for cheating, that policy } \\
\text { would discourage many from plagiarising. }\end{array}$ & 1.901 & 2 & .386 \\
\hline 5. I should not be penalised, if I allow another student to copy my assignment. & 8.478 & 3 & .037 \\
\hline
\end{tabular}

Research question 3: What are the students' reasons for plagiarism?

Table 6 presents the students' reasons for plagiarism, which are sequenced from the most frequently cited to the least cited reasons. The fourth column indicates the typology of reasons as presented in the literature review earlier. $\mathrm{R}$ refers to the typology of reasons listed in column four. 
Table 6. Reasons for plagiarism

\begin{tabular}{|c|c|c|c|}
\hline \multirow[t]{2}{*}{ Reasons for plagiarism } & Yes & No & \multirow[b]{2}{*}{ Typology of Reasons } \\
\hline & No (\%) & No $(\%)$ & \\
\hline 1. I think my written work is not good enough. & $95(79.2)$ & $25(20.8)$ & $\begin{array}{l}\text { Student Inadequacy/ } \\
\text { Writing Skills }\end{array}$ \\
\hline 2. I run out of time. & $87(72.5)$ & $33(27.5)$ & Time Management \\
\hline 3. It is easy to cut and paste from the Internet. & $82(68.3)$ & $38(31.7)$ & $\begin{array}{l}\text { Temptation } \\
\text { Opportunity }\end{array}$ \\
\hline 4. I cannot cope with the workload. & $75(62.5)$ & $45(37.5)$ & Institutional Load \\
\hline $\begin{array}{l}\text { 5. I cannot express another person's ideas in my own } \\
\text { words. }\end{array}$ & $64(53.3)$ & $56(46.7)$ & $\begin{array}{l}\text { Student Inadequacy/ } \\
\text { Writing Skills }\end{array}$ \\
\hline 6. My reading comprehension skills are weak. & $63(52.5)$ & $57(47.5)$ & $\begin{array}{l}\text { Student Inadequacy / } \\
\text { Language Proficiency }\end{array}$ \\
\hline 7. I feel external pressure to succeed. & $63(52.5)$ & $57(47.5)$ & $\begin{array}{l}\text { Personal } \\
\text { Values/Attitudes }\end{array}$ \\
\hline 8. The assignments are too difficult. & $61(50.8)$ & $59(49.2)$ & Institutional Load \\
\hline 9. Plagiarism is not seen as wrong. & $58(48.3)$ & $62(51.7)$ & Denial or Neutralisation \\
\hline 10. I feel the assignment is completely beyond my ability. & $55(45.8)$ & $65(54.2)$ & Denial or Neutralisation \\
\hline $\begin{array}{l}\text { 11. I have always/sometimes copied from other articles/ } \\
\text { sources without any reference or acknowledgment. }\end{array}$ & $52(43.3)$ & $68(56.7)$ & Defiance \\
\hline $\begin{array}{l}\text { 12. The instructions and expectations for assignments are } \\
\text { not clear. }\end{array}$ & $51(42.5)$ & $69(57.5)$ & Denial or Neutralisation \\
\hline 13. I think I will not get caught. & $48(40.0)$ & $72(60.0)$ & Lack of Deterrence \\
\hline $\begin{array}{l}\text { 14. I do not know how to cite and acknowledge the } \\
\text { sources. }\end{array}$ & $46(38.3)$ & $74(61.7)$ & $\begin{array}{l}\text { Genuine Lack } \\
\text { Understanding }\end{array}$ \\
\hline 15. I am not aware of the punishments for plagiarising. & $41(34.2)$ & $79(65.8)$ & $\begin{array}{l}\text { Genuine Lack } \\
\text { Understanding }\end{array}$ \\
\hline 16. There is no faculty/centre control on plagiarism. & $40(33.3)$ & $80(66.7)$ & Lack of Deterrence \\
\hline 17. I think the lecturer will not care. & $37(30.8)$ & $83(69.2)$ & Lack of Deterrence \\
\hline 18. There is no lecturer's control on plagiarism. & $36(30.0)$ & $84(70.0)$ & Lack of Deterrence \\
\hline 19. I copy even if the assignment is easy. & $35(29.2)$ & $85(70.8)$ & Defiance \\
\hline $\begin{array}{l}\text { 20. I do not want to learn anything, but I want } \\
\text { the assignment. }\end{array}$ & $29(24.2)$ & $91(75.8)$ & Efficiency Gain \\
\hline
\end{tabular}

We can see in Table 6 that the two most cited reasons ( $>70 \%$ students) that compel students to plagiarise are their personal self-inadequacy, i.e. in terms of writing skills (R1) and poor time management (R2). The next two reasons that were cited by more than 60 per cent of the students are the temptation and opportunity to plagiarise from the internet (R3) and their inability to cope with the institutional load (R4). Approximately 50 per cent of the students have cited their inadequacies in terms of language proficiency (R5 \& R6), i.e. paraphrasing and reading comprehension skills, external pressure (R7) and institutional load of difficult assignments (R8).

Interestingly, the least cited reasons for plagiarising are lack of deterrence by lecturers, students' defiance, i.e. plagiarising if assignments are difficult and the efficiency gained, i.e. to merely pass the assignments (R18- R20 respectively). These reasons are conversely the most common reasons for not plagiarising ( $\geq 70 \%$ students). 60 69 per cent students stated that they do not plagiarise because they have knowledge on citing and referencing (R14). Other reasons that they gave include deterrence from lecturers, faculty/centre and policy (R13, R15, R16, R17).

Similar to the further analysis conducted on the students' attitudes and their act of plagiarism, their reasons for 
plagiarism were also analysed to see if there were significant difference between the students' reasons and their act of plagiarism. The results of the Pearson Chi Square test are presented in Table 7.

Table 7. Pearson Chi Square results for students' reasons for plagiarism and act of plagiarism

\begin{tabular}{|c|c|c|c|}
\hline \multirow[b]{2}{*}{ Reason } & \multicolumn{3}{|c|}{ Pearson Chi-Square } \\
\hline & Value & $\mathrm{df}$ & $\begin{array}{l}\text { Asymp. Sig } \\
\text { (2 sided) }\end{array}$ \\
\hline 1. I think my written work is not good enough. & 2.141 & 1 & .143 \\
\hline 2. I run out of time. & 6.513 & 1 & .011 \\
\hline 3. It is easy to cut and paste from the Internet. & .650 & 1 & .420 \\
\hline 4. I cannot cope with the workload. & .522 & 1 & .470 \\
\hline 5. I cannot express another person's ideas in my own words. & .031 & 1 & .859 \\
\hline 6. My reading comprehension skills are weak. & 7.158 & 1 & .007 \\
\hline 7. I feel external pressure to succeed. & .149 & 1 & 699 \\
\hline 8. The assignments are too difficult. & 3.100 & 1 & .078 \\
\hline 9. Plagiarism is not seen as wrong. & .151 & 1 & 697 \\
\hline 10. I feel the assignment is completely beyond my ability. & .197 & 1 & .657 \\
\hline $\begin{array}{l}\text { 11. I have always/sometimes copied from other articles/sources without any } \\
\text { reference or acknowledgment. }\end{array}$ & .708 & 1 & .400 \\
\hline 12. The instructions and expectations for assignments are not clear. & 5.355 & 1 & .021 \\
\hline 13. I think I will not get caught. & 3.986 & 1 & .046 \\
\hline 14. I do not know how to cite and acknowledge the sources. & .127 & 1 & .721 \\
\hline 15. I am not aware of the punishments for plagiarising. & .072 & 1 & .789 \\
\hline 16. There is no faculty/centre control on plagiarism. & .174 & 1 & 676 \\
\hline 17. I think the lecturer will not care. & .254 & 1 & .615 \\
\hline 18. There is no lecturer's control on plagiarism. & 4.058 & 1 & .044 \\
\hline 19. I copy even if the assignment is easy. & .246 & 1 & 620 \\
\hline 20. I do not want to learn anything, but I want to just pass the assignment. & 1.148 & 1 & .284 \\
\hline
\end{tabular}

The results of the cross tabulation in Table 7 show that of all the 20 reasons cited, significant differences were found for only five reasons: $\mathrm{R} 2\left(\chi^{2}(1, N=120)=6.513 p=.011\right), \mathrm{R} 6\left(\chi^{2}(1, N=120)=7.158, p=.007\right), \mathrm{R} 13$ $\left(\chi^{2}(1, N=120)=5.355, p=.021\right), \mathrm{R} 13\left(\chi^{2}(1, N=120)=3.986, p=.046\right)$ and $\mathrm{R} 18\left(\chi^{2}(1, N=120)=4.058, p\right.$ $=.044)$. No signification differences were found in the students' act of plagiarism and their other reasons.

Research question 4: What are the Technical and Non-Technical programme students' reasons for plagiarism?

The descriptive statistics of the TP and NTP students' reasons for plagiarising are presented in Table 8. Similar to Table 7, the reasons for plagiarism are sequenced from the most frequently cited to the least cited reasons. 
Table 8 . Reasons for plagiarism by programme

\begin{tabular}{|c|c|c|c|c|c|}
\hline \multirow[b]{3}{*}{ Reasons for Plagiarism } & \multicolumn{2}{|c|}{$\begin{array}{l}\text { Technical } \\
\text { Programme } \\
(N=60)\end{array}$} & \multicolumn{2}{|c|}{$\begin{array}{l}\text { Non-Technical } \\
\text { Programme } \\
(N=60)\end{array}$} & \multirow{3}{*}{ Typology of Reasons } \\
\hline & Yes & No & Yes & No & \\
\hline & $\begin{array}{l}\text { No } \\
(\%)\end{array}$ & $\begin{array}{l}\text { No } \\
(\%)\end{array}$ & $\begin{array}{l}\text { No } \\
(\%)\end{array}$ & $\begin{array}{l}\text { No } \\
(\%)\end{array}$ & \\
\hline 1. I think my written work is not good enough. & $\begin{array}{l}48 \\
(80.0)\end{array}$ & $\begin{array}{l}12 \\
(20.0)\end{array}$ & $\begin{array}{l}47 \\
(78.3)\end{array}$ & $\begin{array}{l}13 \\
(21.7)\end{array}$ & $\begin{array}{l}\text { Student Inadequacy/ } \\
\text { Writing Skills }\end{array}$ \\
\hline 2. I run out of time. & $\begin{array}{l}42 \\
(70.0)\end{array}$ & $\begin{array}{l}18 \\
(30.0)\end{array}$ & $\begin{array}{l}45 \\
(75.0)\end{array}$ & $\begin{array}{l}15 \\
(25.0)\end{array}$ & Time Management \\
\hline 3. It is easy to cut and paste from the Internet. & $\begin{array}{l}41 \\
(68.3)\end{array}$ & $\begin{array}{l}19 \\
(31.7)\end{array}$ & $\begin{array}{l}41 \\
(68.3)\end{array}$ & $\begin{array}{l}19 \\
(31.7)\end{array}$ & $\begin{array}{l}\text { Temptation } \\
\text { Opportunity }\end{array}$ \\
\hline 4. I cannot cope with the workload. & $\begin{array}{l}38 \\
(63.3)\end{array}$ & $\begin{array}{l}22 \\
(36.7)\end{array}$ & $\begin{array}{l}37 \\
(61.7)\end{array}$ & $\begin{array}{l}23 \\
(38.3)\end{array}$ & Institutional Load \\
\hline $\begin{array}{l}\text { 5. I cannot express another person's ideas in } \\
\text { my own words. }\end{array}$ & $\begin{array}{l}36 \\
(60.0)\end{array}$ & $\begin{array}{l}24 \\
(40.0)\end{array}$ & $\begin{array}{l}28 \\
(46.7)\end{array}$ & $\begin{array}{l}32 \\
(53.3)\end{array}$ & $\begin{array}{l}\text { Student Inadequacy/ } \\
\text { Writing Skills }\end{array}$ \\
\hline 6. My reading comprehension skills are weak. & $\begin{array}{l}33 \\
(55.0)\end{array}$ & $\begin{array}{l}27 \\
(45.0)\end{array}$ & $\begin{array}{l}30 \\
(50.0)\end{array}$ & $\begin{array}{l}30 \\
(50.0)\end{array}$ & $\begin{array}{l}\text { Student Inadequacy } \\
\text { Language } \\
\text { Proficiency }\end{array}$ \\
\hline 7. I feel external pressure to succeed. & $\begin{array}{l}37 \\
(61.7)\end{array}$ & $\begin{array}{l}23 \\
(38.3)\end{array}$ & $\begin{array}{l}24 \\
(40.0)\end{array}$ & $\begin{array}{l}36 \\
(60.0)\end{array}$ & $\begin{array}{l}\text { Personal } \\
\text { Values/Attitudes }\end{array}$ \\
\hline 8. The assignments are too difficult. & $\begin{array}{l}32 \\
(53.3)\end{array}$ & $\begin{array}{l}28 \\
(46.7)\end{array}$ & $\begin{array}{l}31 \\
(51.7)\end{array}$ & $\begin{array}{l}29 \\
(48.3)\end{array}$ & Institutional Load \\
\hline 9. Plagiarism is not seen as wrong. & $\begin{array}{l}31 \\
(51.7)\end{array}$ & $\begin{array}{l}29 \\
(48.3)\end{array}$ & $\begin{array}{l}27 \\
(45.0)\end{array}$ & $\begin{array}{l}33 \\
(55.0)\end{array}$ & $\begin{array}{l}\text { Denial } \\
\text { Neutralisation }\end{array}$ \\
\hline $\begin{array}{l}\text { 10. I feel the assignment is completely beyond } \\
\text { my ability. }\end{array}$ & $\begin{array}{l}28 \\
(46.7)\end{array}$ & $\begin{array}{l}32 \\
(53.3)\end{array}$ & $\begin{array}{l}27 \\
(45.0)\end{array}$ & $\begin{array}{l}33 \\
(55.0)\end{array}$ & $\begin{array}{l}\text { Denial } \\
\text { Neutralisation }\end{array}$ \\
\hline $\begin{array}{l}\text { 11. I have always/sometimes copied from other } \\
\text { articles/ sources without any reference or } \\
\text { acknowledgment. }\end{array}$ & $\begin{array}{l}30 \\
(50.0)\end{array}$ & $\begin{array}{l}30 \\
(50.0)\end{array}$ & $\begin{array}{l}22 \\
(36.7)\end{array}$ & $\begin{array}{l}38 \\
(63.3)\end{array}$ & Defiance \\
\hline $\begin{array}{l}\text { 12. The instructions and expectations for } \\
\text { assignments are not clear. }\end{array}$ & $\begin{array}{l}22 \\
(36.7)\end{array}$ & $\begin{array}{l}38 \\
(63.3)\end{array}$ & $\begin{array}{l}29 \\
(48.3)\end{array}$ & $\begin{array}{l}31 \\
(51.7)\end{array}$ & $\begin{array}{l}\text { Denial } \\
\text { Neutralisation }\end{array}$ \\
\hline 13. I think I will not get caught. & $\begin{array}{l}26 \\
(43.3)\end{array}$ & $\begin{array}{l}34 \\
(56.7)\end{array}$ & $\begin{array}{l}22 \\
(36.7)\end{array}$ & $\begin{array}{l}38 \\
(63.3)\end{array}$ & Lack of Deterrence \\
\hline $\begin{array}{l}\text { 14. I do not know how to cite and acknowledge } \\
\text { the sources. }\end{array}$ & $\begin{array}{l}24 \\
(40.0)\end{array}$ & $\begin{array}{l}36 \\
(60.0)\end{array}$ & $\begin{array}{l}22 \\
(36.7)\end{array}$ & $\begin{array}{l}38 \\
(63.3)\end{array}$ & $\begin{array}{l}\text { Genuine Lack of } \\
\text { Understanding }\end{array}$ \\
\hline $\begin{array}{l}\text { 15. I am not aware of the punishments for } \\
\text { plagiarising. }\end{array}$ & $\begin{array}{l}23 \\
(38.3)\end{array}$ & $\begin{array}{l}37 \\
(61.7)\end{array}$ & $\begin{array}{l}18 \\
(30.0)\end{array}$ & $\begin{array}{l}42 \\
(70.0)\end{array}$ & $\begin{array}{l}\text { Genuine Lack of } \\
\text { Understanding }\end{array}$ \\
\hline $\begin{array}{l}\text { 16. There is no faculty/centre control on } \\
\text { plagiarism. }\end{array}$ & $\begin{array}{l}23 \\
(38.3)\end{array}$ & $\begin{array}{l}37 \\
(61.7)\end{array}$ & $\begin{array}{l}17 \\
(28.3)\end{array}$ & $\begin{array}{l}43 \\
(71.7)\end{array}$ & Lack of Deterrence \\
\hline 17. I think the lecturer will not care. & $\begin{array}{l}19 \\
(31.7)\end{array}$ & $\begin{array}{l}41 \\
(68.3)\end{array}$ & $\begin{array}{l}18 \\
(30.0)\end{array}$ & $\begin{array}{l}42 \\
(70.0)\end{array}$ & Lack of Deterrence \\
\hline 18. There is no lecturer's control on plagiarism. & $\begin{array}{l}16 \\
(26.7)\end{array}$ & $\begin{array}{l}44 \\
(73.3)\end{array}$ & $\begin{array}{l}20 \\
(33.3)\end{array}$ & $\begin{array}{l}40 \\
(66.7)\end{array}$ & Lack of Deterrence \\
\hline 19. I copy even if the assignment is easy. & $\begin{array}{l}15 \\
(25.0)\end{array}$ & $\begin{array}{l}45 \\
(75.0)\end{array}$ & $\begin{array}{l}20 \\
(33.3)\end{array}$ & $\begin{array}{l}40 \\
(66.7)\end{array}$ & Defiance \\
\hline
\end{tabular}




$\begin{array}{llllll}\begin{array}{l}\text { 20. I do not want to learn anything, but I want } \\ \text { to just pass the assignment. }\end{array} & \begin{array}{l}13 \\ (21.7)\end{array} & \begin{array}{l}(78.3) \\ \text { (26.7) }\end{array} & \begin{array}{l}(73.3) \\ \text { Efficiency Gain }\end{array}\end{array}$

As seen in Table 8, there is no obvious difference in the reasons why students in both programmes plagiarise or otherwise. The difference ranged from 0 to 21.7 per cent students. While a similar proportion of TP and NTP students (68.3\% students) is found to cite the easily available materials on the internet for plagiarising (S3), a wider difference of 21.7 per cent students is found for citing eternal pressure to succeed (R7). A minimal difference of between 1.6 to 13 per cent students, on the other hand, is found for the other reasons between the two groups. This minimal difference is an indication that both groups of students appear to have almost similar rationales for engaging in plagiarism.

With no obvious difference in the number of students between programmes, as seen in Table 8, it is therefore not surprising to find no significant difference in their reasons, except for being compelled to plagiarise due to external pressure $\left(\chi^{2}(1, N=120)=5.635, p=.018\right)$. The test results are presented in Table 9 .

Table 9. Pearson Chi-Square test results for students' reasons for plagiarising by programme

\begin{tabular}{|c|c|c|c|}
\hline \multirow[b]{2}{*}{ Reason } & \multicolumn{3}{|c|}{ Pearson Chi-Square } \\
\hline & Value & $\mathrm{df}$ & Asymp. Sig (2 sided $)$ \\
\hline 1. I think my written work is not good enough. & .051 & 1 & .822 \\
\hline 2. I run out of time. & .376 & 1 & .540 \\
\hline 3. It is easy to cut and paste from the Internet. & .000 & 1 & 1.000 \\
\hline 4. I cannot cope with the workload. & .036 & 1 & .850 \\
\hline 5. I cannot express another person's ideas in my own words. & 2.143 & 1 & .143 \\
\hline 6. My reading comprehension skills are weak. & .301 & 1 & .583 \\
\hline 7. I feel external pressure to succeed. & 5.635 & 1 & .018 \\
\hline 8. The assignments are too difficult. & .033 & 1 & .855 \\
\hline 9. Plagiarism is not seen as wrong. & .534 & 1 & .465 \\
\hline 10. I feel the assignment is completely beyond my ability. & .034 & 1 & .855 \\
\hline $\begin{array}{l}\text { 11. I have always/sometimes copied from other articles/sources } \\
\text { without any reference or acknowledgment. }\end{array}$ & 2.172 & 1 & .141 \\
\hline 12. The instructions and expectations for assignments are not clear. & 1.671 & 1 & .196 \\
\hline 13. I think I will not get caught. & .556 & 1 & .456 \\
\hline 14. I do not know how to cite and acknowledge the sources. & .141 & 1 & .707 \\
\hline 15. I am not aware of the punishments for plagiarising. & .926 & 1 & .336 \\
\hline 16. There is no faculty/centre control on plagiarism. & 1.350 & 1 & .245 \\
\hline 17. I think the lecturer will not care. & .039 & 1 & .843 \\
\hline 18. There is no lecturer's control on plagiarism. & .635 & 1 & .426 \\
\hline 19. I copy even if the assignment is easy. & 1.008 & 1 & .315 \\
\hline $\begin{array}{l}\text { 20. I do not want to learn anything, but I want to just pass the } \\
\text { assignment. }\end{array}$ & .409 & 1 & .522 \\
\hline
\end{tabular}

\section{Discussion}

Is plagiarism beginning to be rampant in non-English speaking countries? Yes. With 63 per cent students attesting to plagiarising at some point or the other, this study affirms that it is rampant among non-native speakers too. However, it is not at an alarming state as only 1.6 per cent confessed to plagiarising "always". Although not habitual, students in both groups have been involved in academic dishonesty at a lesser degree of frequency; however, the tendency to plagiarise is greater among the TP than NTP students. Whatever may be the 
tendency and frequency of plagiarising, it must be addressed once it has been detected.

Henceforth, discussion of the results of this study is made in accordance to the research question. The first question examined the students' attitudes towards plagiarism. Their attitudes appear to be reflective of their engagement in academic malpractice. In general, the students are not indifferent towards plagiarism. They take it seriously. They consider it as bad as cheating in examinations and submitting downloaded/purchased materials was unacceptable; offenders ought to receive the repercursions of their unethical behaviours-they should be terminated. With such attitudes, it is not surprising to therefore find that it is not a habitual action. Gururajan and Roberts' (2005) found similar attitudes towards 'offenders of wholesale documents', i.e. that they ought to be severely punished. As in the case of the students in Songsriwittaya et al.'s (2009) study, who do not consider it unethical to copy work that their peers have given them permission to do so, students in this study are of the same attitude that as long as consent is granted, no action ought to be taken against them either. As Klein (2011) described, students in this study too take a cavalier attitude. They are not too concerned with self-plagiarism nor with having a policy in place to discourage plagiarism, particularly recording such malpractice in the transcripts. Policies can be in place, but they are not there to deter them. This then leads to the question of enforcement to put a stop to such malpractices. A comparison of the TP and NTP students' attitudes, found similar attitudes towards plagiarism except on terminating students who submit purchased/downloaded papers, but not themselves for allowing their assignments to be copied. Significant differences were found between these groups of students.

The second research question addressed the reasons that compel students to plagiarise. Of the 20 reasons cited, a general pattern found is that personal reasons appear to be more frequently cited, i.e. student inadequacy, poor time management and attitudes/values, i.e. neutralising their engagement. In addition, external factors include the temptation to plagiarise because of availability of the public materials on the internet, the external pressure to succeed and the institutional load. More than 50 per cent of the students cited these reasons. A comparison between the TP and NTP students found that students in both groups tend to hold similar reasons for plagiarism except for the external pressure to succeed. A significant difference was found between the groups. The TP students appear to have greater external pressure to succeed than the NTP students.

Both the personal and external factors tend to govern students' reasons for not plagiarising. While the personal factors, include non-defiance of ethical behaviour, understanding how to cite and awareness of the consequences of being caught as well as their seriousness in acquiring knowledge, the external factors include the deterrence from teachers, faculties or institutions. The remaining 50 per cent of the students cited these reasons. No significant differences were found for these reasons between the two groups.

In terms of order of reasons frequently cited, we found that the three most frequently (more than 68 per cent students) cited reasons are students' poor writing skills, poor time management and the temptation of the available materials on the internet. Poor writing skills was also cited in Pecorari and Petric's (2014) and Debnath's (2016) studies, and time constraints was cited in both Jones' (2011) as well as Eret and Gokmenoglu's (2010) studies.

When we examined the students' act of academic malpractice and their reasons for such practices, we found significant differences for five reasons, i.e. running out of time, poor comprehension skills, unclear instructions/expectations, will not be caught and no lecturer control on plagiarism. These reasons, therefore, may not be reflective of their unethical practices. Students may or may not be compelled to plagiarise.

\section{Conclusion}

As Paldy had noted in 1996 and now after more than 20 years, the problem has not gone away. Macdonald and Carroll (2006) had called for a shared responsibility among students, educators and institutions in addressing this unethical behaviour. We have seen both the students' attitudes and have identified their reasons for plagiarism. Addressing students' constraints that compel them to plagiarise would be a possible resolution. We may not be able to fault the students altogether, if institutions are also not addressing their inadequacies. This study clearly shows that limitations in language proficiency, including reading and writing skills, and poor time management, which are the first two most cited reasons. With such limitations and with the availability of readily available materials on the internet, which is the third most cited reason, it will not be surprising to find students resorting to any easier way of completing their work. Institutions and educators will need to act appropriately in firstly, enhancing students' language proficiency and their writing and comprehension skills. Secondly, educate students on the publicly shared materials on the internet. It is not a communal property, free for all to use as highlighted by Gross (2011). Rather, they need to use them in an ethical manner by acknowledging the source. Thirdly, institutions will also want to revisit the students' academic load. Students may resort to plagiarism if they have to 
undertake a heavy workload. More than 60 per cent of the students reasoned difficult assignments for plagiarising, albeit they are aware of the consequences of plagiarism and are equipped with the knowledge of how to cite.

This study also found that teachers in this institution of higher learning are not taking a lackadaisical stand about deterring students from plagiarising. However, there appears to be a need to scaffold student-learning process and help them cope with the course demands, particularly for the weaker students who may find their assignments to be beyond their capabilities. The plagiarism rate is low for easier assignments than difficult ones. Clearly, in this case, the students take their studies seriously, as efficiency gain is not their concern; they want to learn and are not looking for short cuts.

Students too must understand what constitutes academic dishonesty and not fall prey of the temptation available in the internet. They must understand that plagiarism is unethical. No means of justification can right the wrong. A concerted effort is essential, as all parties must collaborate to put a stop to academic malpractices and unethical behaviour in academic institutions. It is time for all parties to unanimously agree to uphold academic integrity and ethical values.

\section{Reference}

Abdolmohammadi, M. J., \& Baker, C. R. (2007). The relationship between moral reasoning and plagiarism in accounting courses: A replication study. Issues in Accounting Education, 22(1), 45-55. https://doi.org/10.2308/iace.2007.22.1.45

Akbulut, Y., Uysal, O., Odabasi, H.F. \& Kuzu, A. (2008). Influence of Gender, Program of Study and PC Experience on Unethical Computer Using Behaviors of Turkish Undergraduate Students. Computers \& Education, 51(2), 485-492. https://doi.org/10.1016/j.compedu.2007.06.004

Bava Harji, M., Chetty, T. N., Ismail, Z., \& Letchumanan, K. (2016). A Comparison of the Act and Frequency of Plagiarism between Technical and Non-Technical Programme Undergraduates. English Language Teaching, 9(4).

Berlinck, R. G. S. (2011). The academic plagiarism and its punishments - a review. Revista Brasileira de Farmacognosia, 21(3). https://doi.org/10.1590/S0102-695X2011005000099

Brady, J. (2006). Is it just me? Posting on accounting education using computers and multimedia. Archives of Accounting Education Using Computers and Multimedia.

Cheah. J. K. S. (2015). Handbook of Academic Integrity. Singapore: Springer. https://doi.org/10.1007/978-981-287-079-7_5-1

Comas-Forgas, R. \& Sureda-Negre, J. (2010). Academic Plagiarism: Explanatory Factors from Students' Perspective. Journal of Academic Ethics, 8(3), 217-232. https://doi.org/10.1007/s10805-010-9121-0

Davis, S. F., \& Ludvigson, H. W. (1995). Additional data on academic dishonesty and a proposal for remediation. Teaching of Psychology, 22, 119-121. https://doi.org/10.1207/s15328023top2202_6

Debnath, J. (2016). Plagiarism: silent epidemic in scientific writing -Reasons, recognition and remedies. Medical Journal Armed Forces India, 72(2), 164-7. https://doi.org/10.1016/j.mjafi.2016.03.010

Devlin, M. (2003). Educational Integrity: Plagiarism and other perplexities, EBSCO Publishing, University of South Australia.

Devlin, M., \& Gray, K. (2007). In their words: a qualitative study of the reasons Australian university student plagiarize. Higher Education Research and Development, 26(2), 181-198. https://doi.org/10.1080/07294360701310805

Ehrich, J., Howard, S. J., Mu, C., \& Bokosmaty, S. (2014). A comparison of Chinese and Australian university students' attitudes towards plagiarism. Studies in Higher Education, 41(2), 231-246. https://doi.org/10.1080/03075079.2014.927850

Ehrich, J., Howard, S., Tognolini, J., \& Bokosmaty, S. (2015). Measuring attitudes toward plagiarism: issues and psychometric solutions. Journal of Applied Research in Higher Education, 7(2), 243-257. https://doi.org/10.1108/JARHE-02-2014-0013

Eret, E. \& Gokmenoglu, T. (2010). Plagiarism in higher education: A case study with prospective academicians. Procedia Social and Behavioral Sciences, 2, 3303-330. https://doi.org/10.1016/j.sbspro.2010.03.505

Erkaya, O. R. (2009). Plagiarism by Turkish Students: Causes and Solutions. The Asian EFL Journal Quarterly, 
$11(2), 86-103$.

Foltýnek, T., Kravjar, J., \&. Glendinning, I. (2014). Case Study: Policies, Strategies and Responses to Plagiarism in Slovakia, Journal on Efficiency and Responsibility in Education and Science, 7(1), 19-25. https://doi.org/10.7160/eriesj.2014.070104

Gross, E. R. (2011). Clashing values: Contemporary views about cheating and plagiarism compared to traditional beliefs and practices. Education, 123(2), 435-440.

Gururajan, R., \& Roberts, D. (2005). Attitude towards plagiarism in information systems in Australian universities. Paper presented at $9^{\text {th }}$ Pacific Asia Conference on Information Systems (PACIS 2005), 7-10 July 2005, Bangkok, Thailand. Retrieved from https://eprints.usq.edu.au/856/1/Gururajan_Roberts.pdf

Iberahim, H., Hussein, N., Samat, N., Noordin, F., \& Daud, N. (2013). Academic Dishonesty: Why Business Students Participate in these Practices? Procedia - Social and Behavioral Sciences, 90(10), 152-156. https://doi.org/10.1016/j.sbspro.2013.07.076

Harris, R. A. (2001). The plagiarism handbook: Strategies for preventing, detecting, and dealing with plagiarism. California: Eyrczak Publishing.

Higbee, J., \& Thomas, P. (2000). Preventing Academic Dishonesty. Research and Teaching in Developmental Education, 17(1), 63-66. Retrieved from http://www.jstor.org/stable/42802087

Hosny, M. \& Fatima, S. (2014). Attitude of Students Towards Cheating and Plagiarism: University Case Study. Journal of Applied Sciences, 14, 748-757. https://doi.org/10.3923/jas.2014.748.757

Jansz, M. I., \& Sari, N. (2015). Perspectives on Plagiarism in Asia: An exploratory comparative study in Indonesia and Sri Lanka, p. 91In: Proceedings of the International Postgraduate Research Conference 2015. Retrieved from http://repository.kln.ac.lk/handle/123456789/11144

Jiang, H., Emmerton, L., \& McKange, L. (2013). Academic integrity and plagiarism: a review of the influences and risk situations for health students. Higher Education Research and Development, 32(3), 369-380. https://doi.org/10.1080/07294360.2012.687362

Jones, D. L.R. (2011) Academic dishonesty: Are more students cheating? Business Communication Quarterly, 74(2), 141-150. https://doi.org/10.1177/1080569911404059

Klein, D. (2011) Why Learners Choose Plagiarism: A Review of Literature. Interdisciplinary Journal of E-Learning and Learning Objects. 7, 97-110. Retrieved from https://www.learntechlib.org/p/44732

Macdonald R, Carroll J 2006. Plagiarism -a complex issue requiring a holistic institutional approach. Assessment \& Evaluation in Higher Education, 31(2), 233-245. https://doi.org/10.1080/02602930500262536

Mah, F., \& Ting, S. H. (2013). Academic literacy: Plagiarism in pre-university students' academic writing. In: International Conference on Learning and Teaching 28-29 June 2013, Shah Alam, Selangor, Malaysia. https://doi.org/10.1111/jpc.12268

Maurer, H., Kappe, F. \& Zaka, B. (2006). Plagiarism - a Survey. Journal of Universal Computer Science, 12(8), 1050-1084.

Musa, M. K., \& Ting, S. H. (2013). Plagiarism in students' academic writing: Common practices. Proceedings of International Conference on Languages, UPALS (pp. 336-345), Pulau Pinang, Malaysia.

Owunwanne, D., Rustagi, N., \& Dada, R. (2010). Students' perceptions of cheating and plagiarism in higher institutions. Journal of College Teaching and Learning, 7(11), 59-68. https://doi.org/10.19030/tlc.v7i11.253

Park, C. (2003). In other (people's) words: Plagiarism by university students - literature and lessons. Assessment and Evaluation in Higher Education, 28(5), 471-88. https://doi.org/10.1080/02602930301677

Paldy, L. G. (1996). The problem that won't go away: addressing the causes of cheating, Journal of College Science Teaching, 26(1), 4-6.

Pecorari, D., \& Petri ć, B. (2014). Plagiarism in second-language writing. Language Teaching, 47(3), 269-302. https://doi.org/10.1017/S0261444814000056

Pulvers, K., \& Diekhoff, G. M. (1999). The relationship between academic dishonesty and college classroom environment. Research in Higher Education, 40(4), 487-499. https://doi.org/10.1023/A:1018792210076

Razali, S. F. M., Mutalib, A., Hamzah, N., \& Baharom, S. (2016). Plagiarism among first year university students using autocad assignments. Pertanika Journal of Social Science and Humanities, 24(April), 25-34. 
Rezanejad, A., \& Rezaei, S. (2013) Academic Dishonesty at Universities: The Case of Plagiarism Among Iranian Language Students Journal of Academic Ethics, 11(4), 275-295.

Simkin, M. G., \& McLeod, A. (2010). Why do college students cheat? Journal of Business Ethics, 94, 1-445. https://doi.org/10.1007/s10551-009-0275-x

Smith, M., Ghazali, N., \& Minhad, S. F. N. (2007) Attitudes towards plagiarism among undergraduate accounting students: Malaysian evidence. Asian Review of Accounting, 15(2), 122-146. https://doi.org/10.1108/13217340710823350

Songsriwittaya, A., Kongsuwan, S., Jitgarun, K., Kaewkuekool, S., \& Koul, R. (2009). Engineering students' attitude towards plagiarism: A survey study. Education, 69, 9-97.

Ting, S. H. (2013, June 4-5). Academic writing: Citation is troublesome and plagiarism is no big deal. Proceedings of International Conference on Social Science Research, Pulau Pinang, Malaysia. Retrieved from http://ir.unimas.my/717/1/Academic\%2Bwriting\%2Bcitation\%2B\%2528abstract\%2529.pdf

Ting, S. H., Musa, M. K., \& Mah, F. S. F. (2014). Plagiarism Norms and Practices in Coursework Assignments. International Journal of Education, 6(1). 73-89. https://doi.org/10.5296/ije.v6i1.4676

Zobel, J., \& Hamilton, M. (2002). Managing Student Plagiarism in Large Academic Departments. Australian University Review, 45(2), 23-30.

\section{Copyrights}

Copyright for this article is retained by the author(s), with first publication rights granted to the journal.

This is an open-access article distributed under the terms and conditions of the Creative Commons Attribution license (http://creativecommons.org/licenses/by/4.0/). 